\title{
Was Gemma Collin's Toni \& Guy Tweet Misleading?
}

Journal of Direct, Data and Digital Marketing Practice (2012) 14, 168-171. doi:10.1057/dddmp.2012.31

Topic: Social media

Who: ASA, Toni \& Guy

Where: Lakeside Shopping Centre, Essex/Twittersphere

When: 11 July 2012

Law stated as at: 8 August 2012

The Only Way is Essex

\section{What happened}

In a recent adjudication, the Advertising Standards Authority (ASA) ruled that even ad hoc commercial endorsements instigated by celebrities on social media must be labelled as such.

Gemma Collins (' $G C$ '), one of the cast of reality TV show 'The Only Way Is Essex', made two tweets on her personal Twitter account regarding a haircut she had received at Toni \& Guy's hair salon ('T\&G') at Essex shopping centre Lakeside. T\&G had waived the cost of GC's haircut. GC was pleased with this, and 'it was suggested that she tweet about it'. GC had asked whether she should mention a discount, and T\&G had agreed that a 10 per cent discount could be mentioned.

GC posted two tweets promoting the salon (one example is as follows: '10 per cent off @Toniandguylside I have the most amazeballs hair colour and condition best salon ever call and say \#gemma for discount'). A complainant challenged whether these were marketing communications and should be labelled as such.

$\mathrm{T} \& \mathrm{G}$ argued that the mention of a 10 per cent discount should have

No hashtag to indicate tweets were adverts been sufficient to alert followers to the fact that the tweet was a marketing communication. The ASA did not agree, as this could have referred to an existing 10 per cent off promotion. There was no hashtag or wording on the tweets to indicate that they were adverts. They were therefore in breach of the CAP code.

The underlying principle behind this decision: that adverts should be clearly comprehensible as such by the average consumer has been firmly laid down both by the ASA in the CAP Code (rules 2.1 and 2.3) and the Consumer Protection from Unfair Trading Regulations 2008 (the 'CPRs').

The CAP Code provisions are as follows:

'2.1 Marketing communications must be obviously identifiable as such.

2.3 Marketing communications must not falsely claim or imply that the marketer is acting as a consumer or for purposes outside its trade, business, craft or profession; marketing communications 


\section{Is a free haircut a paid-for promotion?}

\section{Commercial bloggers publishing content}

must make clear their commercial intent, if that is not obvious from the context'.

The relevant provisions of the CPRs are 3(4)(b) - which prohibits misleading omissions in commercial practices, and 3(4)(d), which prohibits specific commercial practices listed in Schedule 1. Paragraph 11 of Schedule 1 prohibits:

'Using editorial content in the media to promote a product where a trader has paid for the promotion without making that clear in the content or by images or sounds clearly identifiable by the consumer (advertorial)'.

It is not clear whether the ASA would have found $T \& G$ in breach of the CAP code had T\&G not given GC remuneration in kind in the form of a free haircut. A complimentary haircut, even if of an 'amazeballs' standard, is already a wide interpretation of 'paid for the promotion' in Paragraph 11 of the CPRs above. Certainly if no benefit at all were given to the celebrity there seems a good argument that the CPRs would not have been breached.

It could also be argued that a celebrity tweet promoting a business where no benefit had changed hands would be the celebrity 'acting as a consumer' and therefore not in breach of 2.3 of the CAP Code (although tweeting about a celebrity-linked special offer may be more likely to give the tweet 'commercial intent' as per the same section, even if no actual benefit were given to the celebrity).

\section{Social media marketing 'jurisprudence'}

This adjudication continues the recent line of decisions by regulators defining what is and is not acceptable in terms of marketing on social media.

\section{Blogs: Handpicked media}

The first key case was the Office of Fair Trading (OFT)'s investigation in 2010 of Handpicked Media ('HPM'), a company that employed bloggers on a commercial basis. The OFT was concerned that such commercial bloggers were publishing online content on blogs and Twitter, which promoted the activities of HPM's clients, without sufficient disclosures in place to make it clearly identifiable to consumers that the promotions were being paid for. The OFT made the case that this was clearly incompatible with the CPRs.

The OFT secured undertakings from HPM that it would comply with the CPRs in future by clearly and prominently disclosing on blogs and other commercial posts that the promotion had been paid for or otherwise remunerated.

\section{Twitter: GoNike}

Following this, in 2012, the ASA ruled on Twitter marketing campaigns twice. It found against Nike, who had been running a Twitter campaign with the help of Premier League footballers Wayne Rooney and Jack 
Nike

\section{Rio Ferdinand and Katie Price}

\section{Guidance for marketers using Twitter}

Wilshere. Both footballers had posted tweets on Twitter setting out their footballing resolutions for 2012. The tweets included the hashtag \#makeitcount and a link to a Nike branded website (gonike.me/ makeitcount). However, the ASA did not find that this was a clear enough indication that the tweets were advertising.

The CAP guidance on this released on 20 June 2012 suggests that Nike should have used the hashtag \#ad or \#spon in the message. This is the course of action recommended by the Interactive Advertising Bureau (IAB) and ISBA in their guidance. This would have left viewers in no doubt that the tweet was an advert. While the ASA claims not to be prescriptive about the language used, the fact that it has mentioned these guidelines gives a clear steer towards best practice for advertisers.

\section{Twitter: Snickers}

About the same time as the Nike adverts mentioned above were running, Mars confectionary launched a campaign for its 'Snickers' chocolate bar on Twitter. The premise was that celebrities tweeted several out-of-character tweets, followed by a 'reveal' tweet with the message 'you're not you when you're hungry', a picture of the celebrity holding a Snickers bar, the text@snickersUk and the hashtag '\#spon'. One series had footballer Rio Ferdinand tweeting about knitting, and another had glamour model Katie Price tweeting about the financial crisis.

The ASA received two complaints that the tweets were breaching the CAP code, as it was not clear that the initial four tweets were advertising. However, the ASA found for Mars in this case, as the initial tweets 'did not make any reference to Snickers or Mars' and 'were posted in relatively quick succession' (within a matter of hours). The fifth 'reveal' tweet was clearly labelled as a sponsored communication. This being the case, the ASA felt that consumers would 'understand each series of tweets was a marketing communication'.

\section{Why this matters}

The recent adjudication has made clear that ad hoc tweets by celebrity visitors about a business should be flagged as adverts if there has been any remuneration or instigation by the business, and particularly if the business is making a special offer.

Such situations will render tweets a marketing communication, so \#spon or \#ad should be used.

More generally, this forms another part of the body of guidance for marketers engaging in Twitter campaigns, which is beginning to emerge.

Following HPM, the ASA has shown that it expects a high standard of disclosure when marketing activity is carried out on social media. While the ASA will make allowances for innovative techniques (such as the teaser/reveal tweets in the Snickers campaign), disclosure that such activity is commercial must be made promptly and clearly in all cases. 
The IAB-ISBA 'Guidelines on the Payment for Editorial Content to Promote Brands within Social Media', a revised version of which was published in July 2012, are a good benchmark.

\section{References}

- http://www.asa.org.uk/ASA-action/Adjudications/2012/7/Toni-andGuy-(Lakeside)-Ltd/SHP_ADJ_193054.aspx

- http://www.oft.gov.uk/OFTwork/consumer-enforcement/consumerenforcement-completed/handpicked_media/

- http://www.asa.org.uk/ASA-action/Adjudications/2012/6/Nike-(UK)Ltd/SHP_ADJ_183247.aspx

- http://www.asa.org.uk/ASA-action/Adjudications/2012/3/MarsChocolate-UK-Ltd/SHP_ADJ_185389.aspx

- http://www.iabuk.net/sites/default/files/IAB\%20ISBA\%20Guideline s\%20on\%20the\%20Payment\%20for\%20Editorial\%20Content $\% 20$ $\% 20$ July\%202012.pdf

Thomas Spanyol, Trainee, Osborne Clarke, London Email: Thomas.spanyol@osborneclarke.com

\section{Rise in complaints about unsolicited calls}

Journal of Direct, Data and Digital Marketing Practice (2012) 14, 171-172. doi:10.1057/dddmp.2012.32

Topic: Telemarketing

Who: BBC (Panorama), Ofcom, ICO and the DMA

When: June/July 2012

Where: UK

Law stated as at: 7 August 2012

\section{What happened}

A recent edition of the BBC's 'Panorama' current affairs programme focused on cold callers breaching UK 'do not call' laws ('DNC laws') with apparent impunity.

This was followed closely by a worrying finding in the Information Commissioner's Annual Report for 2011/2012 that complaints about unsolicited marketing calls and texts had shot up by 43 per cent compared to the previous year.

Over 7000 complaints

The Information Commissioner's Office (ICO) had logged nearly 7,100 complaints in 2011/2012, but there was little sign of any significant enforcement action having been taken. Going forward, however, the Information Commissioner did report the setting up of a team dedicated to the enforcement of the regulations that include the 